\title{
Term database for nursing practice in the context of coronavirus (COVID-19) infections
}

Banco de termos para a prática de enfermagem no contexto de infecções por coronavírus (COVID-19)

Banco de términos para la práctica de enfermería en el contexto de las infecciones por coronavirus (COVID-19)

Márcia Cristina de Figueiredo Santos' ORCID: 0000-0002-7246-5814

Ana Márcia Nóbrega Dantas' ORCID: 0000-0001-5729-8512

Rafaela de Melo Araújo Moura ORCID: 0000-0002-8109-6985

Patrícia Josefa Fernandes Beserra' ORCID: 0000-0002-4190-8280

Maria Miriam Lima da Nóbrega' ORCID: 0000-0002-6431-0708

'Universidade Federal da Paraíba. João Pessoa, Paraíba, Brazil.

How to cite this article: Santos MCF, Dantas AMN, Moura RMA, Beserra PJF, Nóbrega MML. Term database for nursing practice in the context of coronavirus (COVID-19) infections. Rev Bras Enferm. 2021;74(Suppl 1):e20200703. https://doi.org/10.1590/0034-7167-2020-0703

Corresponding author:

Márcia Cristina de Figueiredo Santos E-mail:marciacs@hotmail.com

EDITOR IN CHIEF: Dulce Aparecida ASSOCIATE EDITOR: Marcos Brandão

Submission: 06-25-2020 Approval: 01-09-2021

\section{ABSTRACT}

Objective: to build a term database relevant to nursing practice in the context of COVID-19 infections. Methods: this is a methodological, documentary study, carried out from March to June 2020 at ICNP\% Universidade Federal da Paraíba center, considered a reference for research and dissemination of ICNP ${ }^{\oplus}$ in Brazil. The findings were collected in databases and analyzed using the PorOnto tool, the consensus technique and the mapping of terms with ICNP', version 2019/2020. Results: 1,134 relevant terms were identified in literature. When submitted to the mapping technique with the terms of ICNP' Seven Axis Model, it resulted in 531 constant terms and 603 nonconstant terms in this classification. Final considerations: It is proven that nursing practice terms, even in a specific context, are present in the literature and are representative in $\mathrm{ICNP}^{\circ}$, which will enable the future development of a terminological subset in the context of coronavirus infections.

Descriptors: Nursing; Standardized Nursing Terminology; Vocabulary, Controlled; Coronavirus; Infections.

\section{RESUMO}

Objetivo: construir um banco de termos relevantes para a prática de enfermagem no contexto de infecções por COVID-19. Métodos: estudo metodológico, de natureza documental, realizado no período de março a junho de 2020 no Centro CIPE /Universidade Federal da Paraíba, considerado referência para pesquisa e disseminação da CIPE no Brasil. Os achados foram coletados em bases de dados e analisados utilizando a ferramenta PorOnto, a técnica de consenso e o mapeamento dos termos com a CIPE versão 2019/2020. Resultados: identificaram-se 1.134 termos relevantes na literatura, que, quando submetidos à técnica de mapeamento com os termos do Modelo de Sete Eixos da CIPE', resultando em 531 termos constantes e 603 termos não constantes nessa Classificação. Considerações Finais: comprova-se que os termos da prática de enfermagem, mesmo em um contexto específico, estão presentes na literatura e têm representatividade na CIPE', o que possibilitará o desenvolvimento futuro de subconjunto terminológico no contexto de infecções por coronavírus.

Descritores: Enfermagem; Terminologia Padronizada em Enfermagem;Vocabulário Controlado; Coronavírus; Infecções.

\section{RESUMEN}

Objetivo: construir una base de datos de términos relevantes para la práctica de enfermería en el contexto de las infecciones por COVID-19. Métodos: estudio metodológico, de carácter documental, realizado de marzo a junio de 2020 en el Centro CIPE ${ }^{\circ}$ Universidade Federal da Paraíba, considerado un referente para la investigación y difusión del CIPE en Brasil. Los hallazgos fueron recolectados en bases de datos y analizados utilizando la herramienta PorOnto, la técnica de consenso y el mapeo de términos con el CIPE versión 2019/2020. Resultados: se identificaron 1,134 términos relevantes en la literatura, los cuales al ser sometidos a la técnica de mapeo con los términos del Modelo de Siete Ejes de CIPE ${ }^{\circledR}$, resultan en 531 términos constantes y 603 no constantes en esta Clasificación. Consideraciones finales: está comprobado que los términos de la práctica de enfermería, incluso en un contexto específico, están presentes en la literatura y son representativos en la CIPE', lo que permitirá el desarrollo futuro de un subconjunto terminológico en el contexto de las infecciones por coronavirus.

Descriptores: Enfermería; Terminología Normalizada de Enfermería;Vocabulario Controlado; Coronavirus; Infecciones. 


\section{INTRODUCTION}

The pandemic caused by the new coronavirus, also called SARS-CoV-2, emerged with the first case in December 2019 in the city of Wuhan, China ${ }^{(1)}$, with symptoms of atypical pneumonia in humans ${ }^{(2)}$; however, coronavirus species are common in bats and historically there have been two other large outbreaks related to this group of viruses in humans, the first in 2003 with Severe Adult Respiratory Syndrome (SARS-CoV-1) and in 2012 with the appearance of Middle East Respiratory Syndrome (MERS-CoV) ${ }^{(3)}$.

Despite presenting clinical similarity between the forms of presentation of coronavirus, SARS-CoV-2 is the causative agent of COVID-19(4), receiving prominence for its high transmissibility, difficulties for its containment and severity ${ }^{(5)}$. The incubation period for SARS-CoV-2 is quite variable, there are cases of up to 24 days, although it is more common between 2 to 14 days, with a median of 4 to $6^{(6)}$. It is currently known that transmission occurs between humans through symptomatic and asymptomatic patients by oral-fecal route and by aerosol droplets ${ }^{(7)}$.

The main symptoms presented by symptomatic infected patients consist of dry cough, persistent fever (> 37.8C), dyspnea, diarrhea ${ }^{(4,7)}$; other symptoms such as myalgia, nasal congestion, skin changes ${ }^{(4)}$ and ophthalmic and taste disorders may also be common in patients with mild symptoms $z^{(5,8)}$. Among the most severe cases, the patient may present pneumonia, metabolic acidosis, sepsis, hemorrhage ${ }^{(9)}$, renal failure, and death ${ }^{(10)}$.

Strategies, protocols and manuals were developed to guide pandemic emergency situations in order to minimize the impact on society and limit the spread of the virus. Most of these documents are addressed to health professionals, mainly to the nursing team, in order to conduct patient care. Nurses have a centralized role in interpersonal communication with professionals from other areas in the fight against COVID-19 $9^{(11)}$.

Nursing, recognized as a pioneer in patient care and safety, leads an important role in pandemics, wars, epidemics in the development of essential care for patients' needs, such as the principles of hygiene and sanitation observed by Florence Nightingale, who exposed the effectiveness of hand washing to control infections. This practice, widely used in nursing care, shows itself as an ally for coping with COVID-19(11).

The International Council of Nurses (ICN) encourages professionals to work together with society and lists twelve priorities against COVID-19, among which are the encouragement, development, innovation and support of new care models, in addition to implementing a COVID-19 comprehensive and coordinated public health strategy, with active involvement of nurses ${ }^{(12)}$.

That said, to support nurses in developing actions to promote, prevent and intervene with patients, the use of classification systems has been a significant mediator providing support for these actions ${ }^{(13)}$. These systems that are used to standardize nursing practice have been historically disseminated considering the growth and space gained, with emphasis on the International Classification for Nursing Practice (ICNP ${ }^{\circ}$ ), which enables the exercise of complex care by nurses based on a set of knowledge and scientific knowledge ${ }^{(14)}$.

ICNP" is a terminology, characterized as combinatorial, enumerative, with organizing, pre-coordinated and primitive concepts, the latter combining with each other, forming more complex concepts, represented by nursing diagnoses, outcomes and interventions. Furthermore, it is identified as an information technology, as it collects, stores and analyzes nursing information in different scenarios in order to facilitate the understanding of these data between different populations and care ${ }^{(15)}$. It was designed and controlled for use in computer systems as a terminological resource ${ }^{(16)}$.

This classification system is structured in the Seven Axes Model: Focus - area of attention relevant to nursing; Judgment clinical opinion or determination related to the focus of nursing practice; Means - way or method of executing an intervention; Action - intentional process applied to or performed by a client; Time - the moment, period, instant, interval or duration of an occurrence; Location: anatomical or spatial orientation of a diagnosis or interventions; Client - subject to whom the diagnosis refers and who is the beneficiary of a nursing intervention ${ }^{(15,17)}$.

The current version of ICNP' $2019 / 2020$ has 4,475 concepts, 2,440 of which are primitive concepts, of which 1,134 are on the Focus axis, 45 are on the Judgment axis, 235 are on the Action axis, 261 are on the Location axis, 353 are in the Means axis, 70 are on the Time axis, 32 are on the Client axis; 10 organizing concepts; 2,035 are pre-coordinated concepts, with 867 concepts of nursing diagnoses and outcomes (ND/NO) and 1,168 nursing interventions $(\mathrm{NI})^{(18)}$.

Using ICNP' enables the identification, mapping and validation of terms found in the literature records in relation to the terms of ICNP ${ }^{\circ}$ Seven Axis Model ${ }^{(19)}$, construction of specialized clinical terminology and structuring of terminological subsets for specific clientele ${ }^{(18)}$. It is noteworthy that ICN recommends identifying terms applied in nursing for specific areas, aiming at structuring nursing diagnoses, outcomes and interventions ${ }^{(20)}$; considering the current pandemic context, this practice is recognized as being of fundamental importance, considering the need for proper and individualized care.

Considering the above, the question arises: based on terms used in literature and in official documents, can a term database relevant to nursing practice in the context of COVID-19 infections be built? It is emphasized that this term database is an essential step for the construction of elements of nursing practice - nursing diagnoses, outcomes and interventions and, consequently, for the structuring of an ICNP ${ }^{\circ}$ terminology subset in the context of COVID-19 infections.

\section{OBJECTIVE}

To build a term database relevant to nursing practice in the context of COVID-19 infections.

\section{METHODS}

\section{Ethical aspects}

As this is a documentary study, there was no need for approval by an Ethics Committee on Research with Human Beings. Even so, the information selected for analysis was reviewed by the study authors to ensure the reliability of results. 


\section{Type of study}

This is a methodological, documentary study, which was developed from March to June 2020, using ICNP'2019/2020(18) and human mapping according to ISO/TR 12300: $2016^{(16)}$ as theoretical- methodological frameworks.

\section{Methodological procedures}

\section{Study setting}

The study was carried out at ICNP' Graduate Nursing Program at Universidade Federal da Paraíba (PPGENF/UFPB) center, accredited by ICN and considered a reference for research, development and dissemination of ICNP' terminology in Brazil.

\section{Data source}

As recommended by Nóbrega et al. ${ }^{(21)}$, in order to build a term database, the findings were collected in databases and on official literature sites in the area through an integrative literature review guided by the following question of research: what terms of nursing practice are found in literature in the context of COVID-19 infections? Then, the PorOnto tool ${ }^{(22)}$, the Carlson consensus technique(23) and ISO/TR 12300: $2016^{(16)}$ were used to map ICNP' 2019/2020 terms ${ }^{(18)}$.

\section{Data collection and organization}

An integrative literature review was carried out in order to identify the terms considered relevant to nursing practice in the context of COVID-19 infections. To this end, two steps were taken: identification of relevant terms for nursing practice in the context of COVID-19 infections; mapping of terms identified in literature with ICNP' 2019/2020 terms.

The initial selection in the databases resulted in 2,146 articles. After establishing the inclusion and exclusion criteria, demonstrated in the study protocol (Figure 1), the sample was composed of 30 scientific productions, to which 6 official documents from the area were added.

The sample went through a process of removing sections with low potential, such as the authors' section, information about the authors, abstract, footnotes, methodologies, references, acknowledgments, attachments, and appendices. Then, scientific articles were grouped into a single Word ${ }^{\circledR}$ file, which was converted into a portable document format, PDF, called "PDF Literature"; the official documents went through the same process, originating the file called "PDF Official documents of the area", constituting the corpus of the study at this

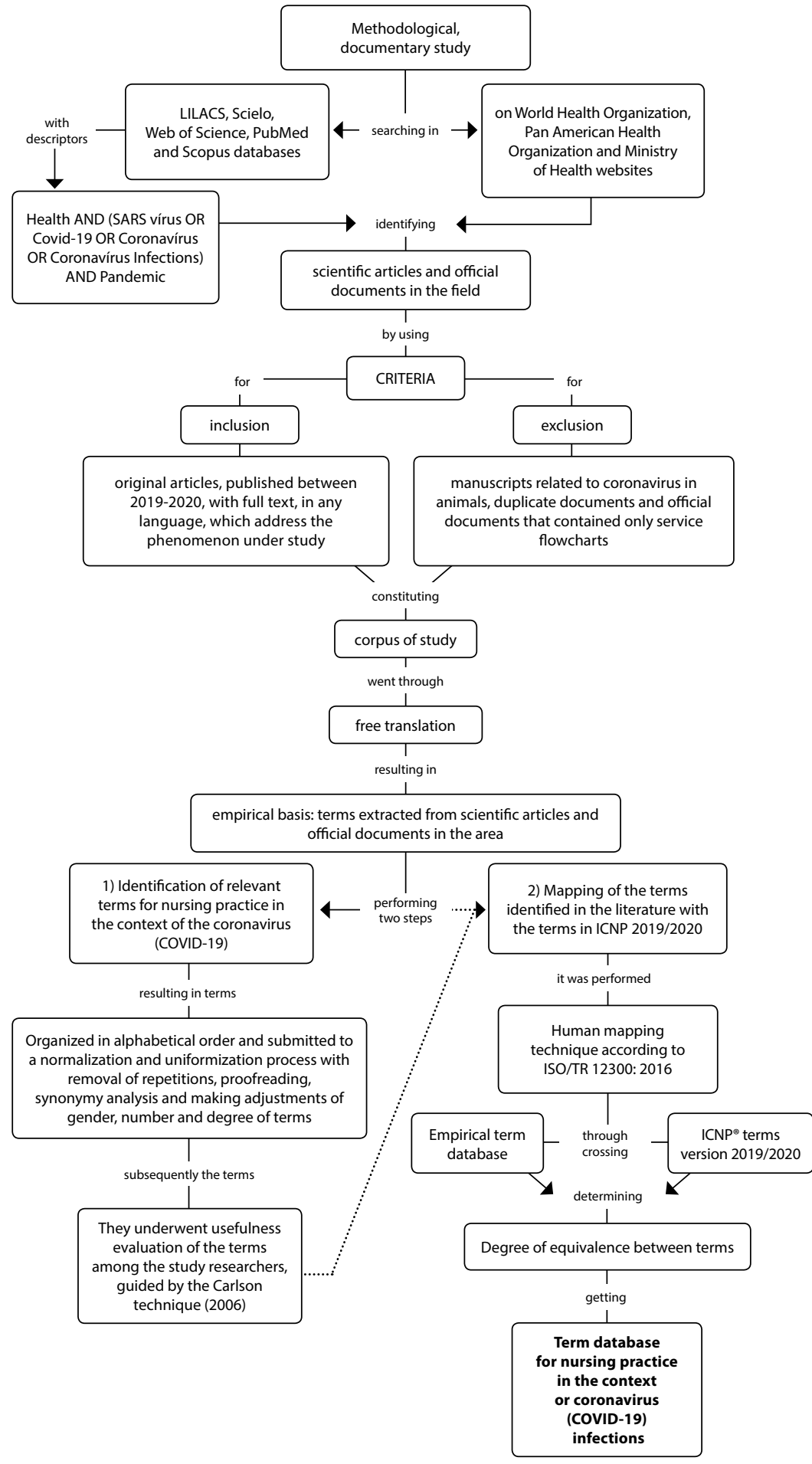

Figure 1 - Methodological description of the study, João Pessoa, Paraíba, Brazil, 2020 research moment. It is noteworthy that the 30 articles and three of the documents resulting from the search were translated (free translation) into Brazilian Portuguese, with the purpose of extracting terms only in this language, considering the use of a tool called PorOnto, which is used for semiautomatic construction of Portuguese ontologies ${ }^{(22)}$ and the subsequent mapping with terms of the Brazilian Portuguese version of ICNP² 2019/2020. Figure 1 presents the methodological description of the study. 


\section{Data analysis}

\section{$1^{\text {st }}$ step-Identification of relevant terms for nursing practice} in the context of COVID-19 infections

In the process of identifying relevant terms for nursing practice in the context of COVID-19 infections, 30 scientific articles and 6 official documents from the area were used. The identification/ extraction process took place using the PorOnto tool, which, in an automated way, processed/crossed two Excel ${ }^{\circ}$ spreadsheets entitled "PDF Literature" and "PDF Official documents of the area", resulting in an Excel spreadsheet entitled "PDF Literature and PDF Official documents of the area", with 15,842 terms. The extracted simple or compound terms, such as nouns, verbs, adverbs, verbal phrases and adverbial phrases, generated a list of terms that were organized in alphabetical order; they were subjected to a process of normalization and standardization with removal of repetitions, correction of spelling, analysis of synonymy and making adjustments of gender, number and degree of terms, as well as the methodological path of other studies developed previously ${ }^{(13,24)}$.

Then, the terms underwent an assessment in relation to clinical utility and cultural relevance for nursing practice in the context of COVID-19 infections. The evaluators were the researchers of the study, given the recommended period of social distance from the coronavirus pandemic and its implications for the population's physical and mental health, making it difficult to recruit other experts, associated with the need for studies that support the systematized care of nursing; this speed could be delayed by submitting the study to a Research Ethics Committee. It is worth mentioning that this remains the future goal of the researchers in this study. Carlson's technique was used to guide the process of evaluating the usefulness of the terms. This technique allows obtaining the opinion or agreement between specialist nurses on a given phenomenon and has been used to refine nursing taxonomies. Among the standards of practice recommended in this process, there is a group composed of three to five clinical specialists and weekly meetings for up to eight months lasting one to two hours. This method highlights the need for $100 \%$ agreement to obtain consensus, not to press for specific decisions and maintain positive attitudes in the face of negative responses ${ }^{(23)}$.

It is noteworthy that the meetings were held online and the instrument used was a spreadsheet in Google Docs, including in it, in addition to the columns with terms and frequency of the same in the literature, columns with the names of each evaluator. This spreadsheet was sent to everyone by e-mail so that everyone was able to view and suggest changes before the meetings.

These meetings were held in May 2020, using communication platforms/tools for chats and video calls (Skype and Google Meet), with the participation of four researchers; among the authors of the manuscript, one is a postdoctoral student and three are doctoral students in nursing, all with experience in scientific research on ICNP ${ }^{\circ}$, nursing process and/or nursing diagnostic language for an average of 13 years; two have direct clinical-care experience (popularly called "the front line") for individuals in the context of coronavirus infections since the beginning of the pandemic in Brazil, professional profiles that represent criteria of expertise in relation to the specific care of interest in the study. Eight online meetings were held, seven lasting two hours and one lasting one hour, adding a workload of 15 hours. The Google Docs spreadsheet was presented/shared by one of the researchers while the evaluation went on from term to term. After this consensus, the second step of the study was carried out.

\section{$2^{\text {nd }}$ step - Mapping of terms identified in literature with ICNP 2019/2020 terms}

The terms identified in the previous step were subjected to the mapping technique which, according to ISO/TR 12300: 2016(16), is configured as human mapping, with one-way direction from the source terms/concepts to the terms/target concepts, that is, from the terms identified in the literature to the terms of the Seven Axis Model of ICNP ${ }^{\circ}$ 2019/2020. In this type of mapping, electronic or computational tools can be used as support, thus, two Excel $^{\circledR}$ spreadsheets were created, one containing the identified terms and the other ICNP ${ }^{\circ}$ terms. These two spreadsheets were imported into the Access for Windows Program, in order to build a table of terms identified in the study to be crossed with the terms of ICNP'2019/2020. Thus, the terms contained and not contained in ICNP ${ }^{\circ}$ were identified.

Subsequently, the degree of equivalence of the nonconstant terms was determined in relation to ICNP' terms as proposed in ISO/TR 12300: $2016^{(16)}$, which establishes a meaning evaluation scale: 1 - Equivalence of lexical and also conceptual meaning (for example, when "abdomen" appears in literature and "abdomen" appears in ICNP $^{\circ}$ ); 2 - Equivalence of meaning, but with synonymy (if the identified term is similar to ICNP ${ }^{\circ}$ term); 3 - The source concept is broader and has less specific meaning than the target concept/ term; 4 - The source concept is more restricted and has more specific meaning than the target concept/term; 5 - No mapping is possible. A concept with some degree of equivalence was not found on the target (as measured by any of the other four assessments). It is noteworthy that when a nonconstant source term was considered equivalent in relations 1 and 2, it was replaced by the equivalent in ICNP', being considered a constant term. The nonconstant source terms analyzed with degree of equivalence 3,4 or 5 in relation to the target terms, were kept as nonconstant terms and were organized within ICNP' Seven Axis Model. At the end of this step, the database was built with terms relevant to nursing practice in the context of COVID-19 infections.

\section{RESULTS}

Thus, 1,134 terms were identified as relevant to nursing practice in the context of COVID-19 infections. These were mapped to the terms of ICNP' 2019/2020 Seven Axis Model, resulting in 603 terms not listed on ICNP $2019 / 2020$ and 531 terms listed on ICNP' 2019/2020.

The terms in literature that made up the term database as constant terms from the equivalence assessment 1 in relation to ICNP' 2019/2020 terms totaled 23 terms; those that became constant terms from the equivalence assessment 2 were 118 terms; the other 390 constant terms did not undergo equivalence assessment, as their constancy on ICNP $2019 / 2020$ as stated in the literature 
had already been verified by the mapping process. The number of nonconstant terms evaluated in equivalence degree 3 in relation to ICNP $^{\circ}$ 2019/2020 terms was 71, based on this equivalence, remaining as nonconstant terms. The terms evaluated in degree of equivalence 4 in relation to ICNP ${ }^{\circ}$ terms were 22 terms and those evaluated in degree of equivalence 5 totaled 510 terms.

Among the 531 constant terms, 125 make up the Action axis, 17 make up the Client axis, 227 make up the Focus axis, 32 make up the Judgment axis, 59 the Location axis, 50 the Means axis and 21 the Time axis. Chart 1 presents an excerpt that exemplifies such terms.

Chart 1 - Examples of terms identified in the literature and classified as constant in ICNP"2019/2020, João Pessoa, Paraíba, Brazil, 2020

\begin{tabular}{|l|l|}
\hline A & \multicolumn{1}{|c|}{ Constant terms } \\
\hline F & $\begin{array}{l}\text { Anguish; Anxiety; Self-care; Congestion; Knowledge about } \\
\text { Behavior Change Process; Contamination; Dyspnea; Pain; Side } \\
\text { effect; Environmental Entity; Fatigue; Fever; Hand Hygiene; } \\
\text { Hypertension; Infection; Social isolation; Obesity; Smell; Blood } \\
\text { Oxygen Saturation; Vital Sign; Decision-Making, Effective; Cough; } \\
\text { Gas exchange. }\end{array}$ \\
\hline J & Dependency; Mild; Improved; Moderate; Impaired; Risk. \\
\hline M & $\begin{array}{l}\text { Communication Device; Interprofessional Team; Mask; } \\
\text { Medication; Oxygen therapy; Vaccine. }\end{array}$ \\
\hline A & $\begin{array}{l}\text { Administering; Feeding; Describing; Encouraging; Establishing; } \\
\text { Running; Managing; Sanitizing (or Promoting Hygiene); } \\
\text { Identifying; Notifying; Observing; Registering; Supervising. }\end{array}$ \\
\hline T & Admission; Acute; Chronic; Duration; Exam; Frequency. \\
\hline C & Community; Caregiver; Family; Group; Elder; Individual. \\
\hline L & $\begin{array}{l}\text { Hospital; Prone (or prone position); Chest; Intravenous (or } \\
\text { Endovenous); Nasal route; Oral route. }\end{array}$ \\
\hline
\end{tabular}

Chart 2 - Examples of terms identified in literature and classified as not included in ICNP 2019/2020, João Pessoa, Paraíba, Brazil, 2020

\begin{tabular}{|l|l|}
\hline A & \multicolumn{1}{|c|}{ Nonconstant terms } \\
\hline F & $\begin{array}{l}\text { Reception; Crowding; Assistance; Self-medication; Flap Nose } \\
\text { Wing; Biosafety; Headache; Cyanosis; Science; Alveolar collapse; } \\
\text { Contagion; Coronavirus; Disinfection; Distancing; Strategy; } \\
\text { Respiratory label; Bacterial infection; Viral infection; Monitoring; } \\
\text { Level of consciousness; Pandemic; Health promotion; Pulse; Adverse } \\
\text { reaction; Recommendation; Record; Immune response; Mental } \\
\text { health; Symptomatology; Respiratory sounds; COVID suspicion; } \\
\text { Reference values. }\end{array}$ \\
\hline J & $\begin{array}{l}\text { Accelerated; Atypical; Decreased; Normal limits; Persistent; } \\
\text { Satisfactory. }\end{array}$ \\
\hline A & $\begin{array}{l}\text { Assisting; Sizing; Elaborating; Deploying; Preserving; } \\
\text { Recommending; Suspending. }\end{array}$ \\
\hline M & $\begin{array}{l}\text { Antiseptic; Elevated headboard; Individual protection equipment; } \\
\text { Nursing team; Gasometry; Decubitus change; Mechanical } \\
\text { ventilation; Serum; Oxygen support; Nasopharyngeal swab. }\end{array}$ \\
\hline T & Phase; Incubation; Initial; Period; Permanence; Quarantine. \\
\hline C & Man; Indian; Lactating; Woman; Person; Population. \\
\hline L & $\begin{array}{l}\text { Reference Center; Residence; Long-stay institution; Accessory } \\
\text { musculature; Organ; Respiratory tract. }\end{array}$ \\
\hline Note: A:ICNP axis; F: Focus; J: Judgment; A: Action; M: Means; T: Time; Ç: Client; L: Location.
\end{tabular}

Among the 603 nonconstant terms, 78 terms were classified on the Action axis, 14 were classified on the Client axis, 313 were classified on the Focus axis, 53 on the Judgment axis, 33 on the Location axis, 93 on the Means axis and 19 on the Time axis. Chart 2 shows an example.

\section{DISCUSSION}

The structuring of a term database for professional nursing practice represents a specialized professional language and brings together terms/concepts that indicate the knowledge domain phenomena in this area. When the understanding of these terms is effective, their potential for practical applicability rises and generates visibility to the work developed ${ }^{(25)}$.

Considering that ICNP ${ }^{\circ}$ terms represent a professional language that supports assistance planning to the relevant areas of care for nursing and that the term database built in this study brings together a significant number of terms contained in its various axes, it is suggested that, despite the complexity and specificity in patient care in the context of infections by COVID-19 and being a disease of recent appearance, nursing is already known to live with the use of some terms in its professional practice. Moreover, professionals still have terms in literature that are specific to the phenomenon of interest and that are not included in the classification system, corroborating the inference that the term database produced constitutes a useful instrument in nursing care in the context of infection by COVID-19.

In the Focus axis, among the constant terms, some terms stand out regarding the thematic relevance, among them there is the Dyspnea term, which is a phenomenon of interest to nursing care, because when associated with the flu syndrome, it is considered a clinical manifestation considered as a sign of severity of COVID-19 that should be valued, indicating the need for individuals to seek health care in a Reference/Specialized Care Center ${ }^{(26)}$; this is represented among the nonconstant terms, in the Location axis. Dyspnea is still considered one of the most prevalent symptoms at the beginning of the disease in patients who died of COVID-19 and is more commonly expressed in these patients than in patients recovered from the disease ${ }^{(27)}$.

Concerning the Focus axis, other terms are relevant, such as Knowledge about the Behavior Change and Decision-Making Process, Effective; both are directly related to measures to control coronavirus infections that require safe and effective prevention decision-making, in order to make clients emancipated and autonomous, involving them as a person, member of a family and/or community co-responsible for preventing the disease from spreading ${ }^{(28-29)}$.

Among the terms contained in the Judgment axis, the Impaired term stands out, widely used among ICNP ${ }^{\circ}$ diagnostic statement proposals whenever it is intended to refer to the judgment of a negative or ineffective state in a given phenomenon ${ }^{(18)}$.

Under the terms contained in the Means axis, the Oxygen therapy term is available, where the performance of nursing involves diverse care, especially aspects such as testing and installation of devices, monitoring, checking alarms, initial adjustment and handling of parameters, under medical coordination ${ }^{(30)}$.

In the Action axis, among the constant terms, the Registering term refers to the main interest of the final product of this study in 
supporting an effective, standardized and universal registration for nursing care in a specific context; it also meets what is legally established as an essential role of nurses, where the formal record of the execution of the Nursing Process is configured as a duty of these professionals ${ }^{(31)}$.

In the Time axis, among the constant terms, the Duration term refers to the context of periodization of a processes involved in assisting affected individuals, whether it be the hospitalization process, which has generally extended for a prolonged period (up to 27 days), whether the duration of symptoms, such as fever persisting for an average of 10 days ${ }^{(32)}$, or even in other contexts, making it important to have this term for the proper record of the care provided.

Among the terms classified in the Client axis, the Person term, not included in ICNP', stands out; is configured as a target/destination of nursing care due to its principle definition in the code of ethics, as well as Family and Community terms, contained in ICNP', since nursing is based on its professional performance, commitment to the production and management of care in different socio-environmental and cultural contexts in response to the needs of a person, family and community ${ }^{(33)}$.

The context of prevention of coronavirus infections involves several assertive behaviors, such as washing hands with soap and water or cleaning with gel alcohol; use of "respiratory etiquette", i.e., cover the nose and mouth when sneezing or coughing; social distance; not sharing personal objects; maintenance of ventilation in environments ${ }^{(28-29)}$. Terms that relate to COVID-19 pandemic control measures have undeniable relevance and were contextualized above, being Environmental Entity, Hand Hygiene, and Social Isolation, all contained on the ICNP Focus axis. Social isolation is recognized as the most effective measure to reduce the virus transmissibility ${ }^{(34)}$. However, it significantly affects individuals' quality of life, intensifying feelings of negative emotion - a term that is constant on the ICNP' Focus axis ${ }^{(35)}$. The need to minimize this reality gives space to the communication devices - a constant term on the ICNP' Means axis - that have proven to be true allies to the confrontation of the pandemic by the population, enabling social interaction by favoring communication between people ${ }^{(1)}$.

The Prone Position term, in turn, appears as a component of the Location axis and refers to positioning the individual's body, in which patients remain lying on their abdomen, with their arms and legs longitudinal to the body, with head turned to one $\operatorname{side}^{(36)}$. It is believed that such a position favors better body oxygenation due to the improvement in the ventilation/ perfusion ratio, but it is worth highlighting the need for patient safety for the intervention to be effective ${ }^{(37)}$. It is essential that nurses act responsibly regarding the decision-making process (also the focus of nursing care/constant term in ICNP ${ }^{\circ}$ ), performance and/or prescription of procedures related to pronation of patients on mechanical ventilation and application of care to prevent potential incidents ${ }^{(30)}$.

The prone position has no evidence to be routinely recommended to individuals on spontaneous ventilation; however, it is indicated for oxygenation by mechanical ventilation (nonconstant term in ICNP', classified in the Means axis) ${ }^{(37)}$. Recent findings show that more deceased than recovered patients underwent mechanical ventilation, portraying a negative outcome in cases where this type of intervention is necessary ${ }^{(27)}$.

Regarding nonconstant terms, in the Focus axis there is the Biosafety term as a phenomenon of interest to nursing care provided to the individual in the context of COVID-29 infection, because it involves a universe of biological exposure, whether it be to body fluids, droplets, aerosols, among others, which requires planning and work organization. Biosafety involves professional protection measures necessary in this coronavirus pandemic time to all essential work groups ${ }^{(38)}$. Although the need for individual protection of health professionals has gained a deserved prominence in this pandemic, there are still union struggles intended to achieve better working conditions and greater availability of Personal Protective Equipment (PPE) ${ }^{(39)}$ - even considered in this study as a relevant term, not included in ICNP', classified in the Means axis, as it is essential to prevent the disease from spreading by protecting the professional who provides care to the clientele of interest ${ }^{(40)}$.

Among the terms not included in ICNP', classified in the Focus axis, the Mental Health term stands out, given the imbalance routinely faced by people before the uncertainty and low predictability of COVID-19 ${ }^{(35)}$. In addition to providing care to individuals and family members, the Nursing Team (nonconstant term classified in the Means axis) also faces associated factors, such as long working hours, sleep deprivation and basic needs, as well as the fear of being infected and spreading the virus to their families $^{(11)}$, potentially elevating mental comorbidities, namely, post-traumatic stress, anxiety, and depression ${ }^{(1)}$.

In the Action axis, among the nonconstant terms, there is the Assisting term, which is a fundamental part of nursing care based on own knowledge, configuring an action performed in professional and social practice, where nurses assist manage, teach, educate and research based on technical and legal support ${ }^{(33)}$.

The Decreased term, nonconstant in ICNP', classified in the Judgment axis, is a term already used in ICNP's pre-coordinated concepts, most frequently in positive nursing diagnoses/outcomes, representing some level of adjustment to a lower level in particular finding or body response ${ }^{(18)}$.

In the Time axis, among the terms not included in ICNP', the Quarantine term represents the community containment that has been necessary as an action to prevent contamination of the population by COVID-19 during a period of 14 days specifically ${ }^{(41)}$, which may have other durations depending on assistance criteria.

It is understood that the future research objectives are guided by the theoretical definition of the terms that make up the database structured in this study, as well as by the elaboration of proposals for diagnostic concepts/nursing outcomes and nursing interventions.

\section{Study limitations}

As a study limitation, the current situation of social isolation stands out, which makes communication between researchers difficult. The only means of communication for the meetings were digital platforms/online communication tools, depending on quality internet, not always available, thus burdening the time of this study. 


\section{Contributions to nursing, health, and public policy}

It is believed that the results of this study make important contributions to nursing knowledge so that the structured database term strengthens its standardized language, corroborating the development and/or operationalization of clinical terminologies and ICNP" use as a useful technological tool and relevant to nursing.

\section{FINAL CONSIDERATIONS}

As intended, 1,134 terms were identified which, when mapped with ICNP' 2019/2020, resulted in 531 (46.8\%) constant terms and $603(53.2 \%)$ not included in ICNP', showing a predominance of terms allocated to the Focus axis - 541 (47.7\%), of which 227 are constant and 313 are nonconstant. The other axes correspond: $203(17.9 \%)$ terms in the Action axis, being 125 constant and 78 nonconstant; 143 (12.6\%) terms in the Means axis, with 50 being constant and 93 nonconstant; 92 (8.1\%) terms in the Location axis, with 59 being constant and 33 nonconstant; 85 (7.5\%) terms on the Judgment axis, 32 of which are constant and 53 nonconstant; $40(3.5 \%)$ terms on the Time axis, 21 of which are constant and 19 nonconstant; 31 (2.7\%) terms in the Client axis, 17 of which are constant and 14 nonconstant.

This study, therefore, represents the possibility of applying ICNP ${ }^{\circ}$ in a specific context of assistance to the person, family and community, so that it generates evidence about its effectiveness in relation to the Nursing Process, strengthening the importance of its use.

\section{REFERENCES}

1. Zhang Y, Ma ZF. Impact of the COVID-19 pandemic on mental health and quality of life among local residents in Liaoning Province, China: a cross-sectional study. Int J Environ Res Public Health. 2020;17(7): 2381. https://doi.org/10.3390/ijerph17072381

2. Baghchechi M, Dunn J, Jaipaul N, Jacob SE. Art of prevention: life in the time of coronavirus. Int J Wom Dermatol. 2020. Preprint. https://doi. org/10.1016/j.jijwd.2020.03.046

3. Sönnerborg A. Fladdermöss och människor [Bats and humans]. Lakartidningen [Internet]. 2020 [cited 21 May 2020];117:F3UA. Available from: https://pubmed.ncbi.nlm.nih.gov/32365214/

4. Organização Mundial da Saúde (OMS). Folha informativa - COVID-19 (doença causada pelo novo coronavírus) [Internet]. 2020 [cited 21 May 2020]. Available from: https://www.paho.org/bra/index.php?option=com_content\&view=article\&id=6101:covid19\&ltemid=875.

5. Ministério da Saúde (BR). Secretaria de Vigilância em Saúde. Infecção Humana pelo Novo Coronavírus (2019-nCoV) [Internet]. 2020 [cited 04 Jun 2020]. Available from: https://www.fcv.org.br/site/upload/editor/20200221114456_755450.pdf

6. Bai Y, Yao L, Wei T, Tian F, Jin DY, Chen L, et al. Presumed asymptomatic carrier transmission of Covid - 19. JAMA. 2020;323(14): 1-2. https:// doi.org/10.1001/Jama.2020.2565

7. Zhou P, Yang XL, Wang XG, Hu B, Zhang L, Zhang W, et al. A pneumonia outbreak associated with a new coronavirus of probable bat origin . Nature. 2020;579: 270-273. https://doi.org/10.1038/s41586-020-2012-7

8. Luers JC, Rokohl AC, Loreck N, Matos PAW, Augustin M, et al. Olfactory and gustatory dysfunction in Coronavirus Disease 19 (COVID-19). Clin Infect Dis. 2020. Preprint. https://doi.org/10.1093/cid/ciaa525

9. Li J-Y, You Z, Wang Q, Zhou Z-J, Qiu Y, Luo R, et al. The epidemic of 2019-novel-coronavirus (2019-nCoV) pneumonia and insights for emerging infectious diseases in the future. Microb Infect. 2020;22(2):80-85. https://doi.org/10.1016/j.micinf.2020.02.002

10. Huang C, Wang Y, Li X, Ren L, Zhao J, Hu Y, et al. Clinical features of patients infected with 2019 novel coronavirus in Wuhan, China. Lancet. 2020;395:497-506. https://doi.org/10.1016/S0140-6736(20)30183-5

11. Buheji M, Buhaid N. Nursing human factor during COVID-19 pandemic. Int J Nurs Sci. 2020;10(1):12-24. https://doi.org/10.5923/j.nursing.20201001.02

12. International Council of Nurses (ICN). ICN highlights top priorities to beat COVID-19 [Internet]. Geneva, Switzerland: ICN; 2020 [cited 21 May 2020]. Available from: https://www.icn.ch/news/icn-highlights-top-priorities-beat-covid-19.

13. Siqueira MCF, Bittencourt GKG, Nóbrega MML, Nogueira JA, Silva AO. Term base for nursing practices with elderly women with HIV/AIDS. Rev Gaúcha Enferm. 2015;36(1):28-34. https://doi.org/10.1590/1983-1447.2015.01.46671.

14. Beserra PJF, Gomes GLL, Santos MCF, Bittencourt GKGD, Nóbrega MML. Scientific production of the international Classification for Nursing Pratice: a bibliometric study. Rev Bras Enferm. 2018;71(6): 2860-8. https://doi.org/10.1590/0034-7167-2017-0411.

15. Garcia TR, Nóbrega MML, Cubas MR. CIPE ${ }^{\oplus}$ : uma linguagem padronizada para a prática profissional. In: Garcia TR.(org). Classificação Internacional para a Prática de Enfermagem (CIPE ${ }^{\oplus}$ ): versão 2019/2020. Porto Alegre: Artmed; 2020.p 21-35.

16. International Organization for Standardization. ISO 12.300 - Health Informatics: Health informatics - Principles of mapping between terminological systems. Geneva: ISO; 2016. 1-46p.

17. International Organization for Standardization. ISO 18.104. Health Informatics: Categorial structures for representation of nursing diagnoses and nursing actions in terminological systems. Geneve: ISO; 2016.p- 1-33.

18. Garcia TR. Classificação Internacional para a Prática de Enfermagem (CIPE ): versão 2019/2020. Porto Alegre: Artmed; $2020 . p$ 1-270.

19. Félix NDC, Nascimento MNR, Ramos NM, Oliveira CJ, Nóbrega MML. Specialized nursing terminology for the care of people with metabolic syndrome. Esc Anna Nery. 2020;24(3):e20190345. https://doi.org/10.1590/2177-9465-EAN-2019-0345 
20. International Council of Nurses (ICN). Guidelines for ICNP catalogue development [Internet] . Geneve, Switzerland: ICN; 2018 [cited 21 May 2020 ]. Available from: https://www.icn.ch/sites/default/files/inline-files/Guidelines\%20for\%20ICNP\%20Catalogue\%20Development\%202018_0.pdf

21. Nóbrega MML, Cubas MR, Egry EY, Nogueira LGF, Carvalho CMG, Albuquerque LM. Desenvolvimento de subconjuntos terminológicos da CIPE ${ }^{\oplus}$ no Brasil. In: Cubas MR, Nóbrega MML. Atenção primária em saúde: diagnósticos, resultados e intervenções de enfermagem. Rio de Janeiro: Elsevier; 2015. p.3-24.

22. Zahra FM, Carvalho DR, Malucelli A. [Poronto: tool for semi-automatic ontology construction in portuguese]. J. Health Inform [Internet]. 2013 [cited 2020 Jun 19];5(2): 52-9. Available from: http://www.jhi-sbis.saude.ws/ojs-jhi/index.php/jhi-sbis/article/view/232 Portuguese.

23. Carlson J. Consensus validation process: a standardized research method to identify and link the relevant NANDA, NIC and NOC terms for local populations. Int J Nurs Terminol Classif [Internet]. 2006 [cited 20 Apr 2020];17(1)23-4. Available from: http://onlinelibrary.wiley.com/ doi/10.1111/ijnt.2006.17.issue-1/issuetoc

24. Beserra PJF. Subconjunto terminológico da CIPE ${ }^{\circledast}$ para mulheres com HIV e AIDS [Tese] [Internet]. João Pessoa: Programa de PósGraduação em Enfermagem, Universidade Federal da Paraíba; 2018[cited 20 Apr 2020]. Available from: https://repositorio.ufpb.br/jspui/ handle/123456789/16968

25. Garcia TR. Professional language and nursing domain. Texto Contexto Enferm. 2019;28:e20190102. https://doi. org/10.1590/1980-265x-tce-2019-0001-0002.

26. Ministério da Saúde (BR). Secretaria de Atenção Primária à Saúde. Protocolo de manejo clínico do coronavírus (COVID-19) na Atenção Primária à Saúde [Internet]. Brasília: Ministério da Saúde; 2020 [cited 24 May 2020]. Available from: https://portalarquivos.saude.gov.br/ images/pdf/2020/April/08/20200408-ProtocoloManejo-ver07.pdf.

27. Chen T, Wu D, Chen H, Yan W, Yang D, Chen G, et al. Clinical characteristics of 113 deceased patients with coronavirus disease 2019: retrospective study. BMJ. 2020;368:m1091. https://doi.org/10.1136/bmj.m1091

28. Oliveira WK, Duarte E, França GVA, Garcia LP. How Brazil can hold back COVID-19. Epidemiol Serv Saúde. 2020;29(2):e2020044. https://doi. org/10.5123/S1679-49742020000200023

29. Barreto ML, Barros AJD, Carvalho MS, Codeço CT, Halla PRC, Medronho RA, et al. [What is urgent and necessary to inform policies to deal with the COVID-19 pandemic in Brazil?]. Rev. Bras. Epidemiol. 2020; 23: e200032. https://doi.org/10.1590/1980-549720200032 Portuguese.

30. Conselho Federal de Enfermagem (COFEN). Resolução COFEN n 639/2020. Dispõe sobre as competências do Enfermeiro no cuidado aos pacientes em ventilação mecânica no ambiente extra e intra-hospitalar [Internet]. Brasília: COFEN; 2020 [cited 02 Jun 2020]. Available from: http://www.cofen.gov.br/resolucao-cofen-no-639-2020_79633.html

31. Conselho Federal de Enfermagem (COFEN). Resolução COFEN n 358/2009. Dispõe sobre a Sistematização da Assistência de Enfermagem e a implementação do Processo de Enfermagem em ambientes, públicos ou privados, em que ocorre o cuidado profissional de Enfermagem, e dá outras providências [Internet]. Brasília: COFEN; 2009 [cited 01 Jun 2020]. Available from: http://www.cofen.gov.br/resoluocofen-3582009_4384.html

32. Burhan E, Prasenohadi P, Rogayah R, Isbaniyah F, Dharmawan I. Clinical Progression of COVID-19 patient with extended incubation period, delayed RT-PCR time-to-positivity, and potential role of chest CT-scan. Acta Med Indones [Internet]. 2020 [cited 2020 Jun 10];52(1):80-3. Available from: https://pubmed.ncbi.nlm.nih.gov/32291376/

33. Conselho Federal de Enfermagem (COFEN). Resolução COFEN № 564/2017. Dispõe sobre o Código de Ética dos Profissionais de Enfermagem [Internet]. Brasília: COFEN; 2017 [cited 05 Jun 2020]. Available from: http://www.cofen.gov.br/resolucao-cofenno-5642017_59145.html.

34. Su L, Ma X, Yu H, Zhang Z, Bian P, Han Y, et al. The different clinical characteristics of corona virus disease cases between children and their families in China - the character of children with COVID-19. Emerg Microbes Infect. 2020;9(1):707-13. https://doi.org/10.1080/22221751.2020.1744483

35. Li S, Wang Y, Xue J, Zhao N, Zhu T. The Impact of COVID-19 Epidemic Declaration on Psychological Consequences: A Study on Active Weibo Users. Int. J. Environ. Res. Public Health. 2020; 17(6): 2032. https://doi.org/10.3390/ijerph17062032

36. Paiva KCA, Beppu OS. Prone position. J Bras Pneumol. 2005;31(4):332-40. https://doi.org/10.1590/S1806-37132005000400011

37. Associação de Medicina Intensiva Brasileira. Orientações sobre o manuseio do paciente com pneumonia e insuficiência respiratória devido a infecção pelo Coronavírus (SARS-CoV-2) [Internet] São Paulo: AMIB; 2020 [cited 2020 Jun 04]. Available from: https://www.amib. org.br/fileadmin/user_upload/amib/2020/marco/29/Orientacoes_sobre_o_manuseio_do_paciente_com_pneumonia_e_insuficiencia_ respiratoria_devido_a_infeccao_pelo_Coronavirus_SARS-CoV-2_-_Versao_n.032020.pdf

38. Jackson Filho JM, Assunção AA, Algranti E, Garcia EG, Saito CA, Magno M. [Worker's health and the struggle against COVID-19]. Rev Bras Saude Ocup. 2020; 45:e14. https://doi.org/10.1590/2317-6369ed0000120. Portuguese.

39. Associação Médica Brasileira. Faltam EPIs em todo o país [Internet] São Paulo: AMB; 2020 [cited 2020 Jun 8]. Available from: https://amb.org. br/epi/

40. Ministério da Saúde (BR). Secretaria de Atenção Especializada à Saúde. Protocolo de manejo clínico da Covid-19 na Atenção Especializada [Internet]. Brasília: Ministério da Saúde; 2020 [cited 2020 May 21]. Available from: https://portalarquivos.saude.gov.br/images/pdf/2020/ April/14/Protocolo-de-Manejo-Cl--nico-para-o-Covid-19.pdf

41. Mash B. Primary care management of the coronavirus (COVID-19). S Afr Fam Pract. 2020;62(1):e1-e4a5144. https://doi.org/10.4102/safp. v62i1.5144 